\title{
Patterns of pollen and seed dispersal in a small, fragmented population of the wind-pollinated tree Araucaria angustifolia in southern Brazil
}

\author{
JVM Bittencourt ${ }^{1}$ and AM Sebbenn ${ }^{2}$ \\ ${ }^{1}$ Department of Geography, University of Reading, Berkshire, UK and ${ }^{2}$ Seção de Genética Florestal, Instituto Florestal de São Paulo, \\ São Paulo, Brazil
}

\begin{abstract}
Paternity analysis based on eight microsatellite loci was used to investigate pollen and seed dispersal patterns of the dioecious wind-pollinated tree, Araucaria angustifolia. The study sites were a 5.4 ha isolated forest fragment and a small tree group situated $1.7 \mathrm{~km}$ away, located in Paran $\alpha$ State, Brazil. In the forest fragment, 121 males, 99 females, 66 seedlings and 92 juveniles were mapped and genotyped, together with 210 seeds. In the tree group, nine male and two female adults were mapped and genotyped, together with 20 seeds. Paternity analysis within the forest fragment indicated that at least $4 \%$ of the seeds, $3 \%$ of the seedlings and $7 \%$ of the juveniles were fertilized by pollen from trees in the adjacent group, and $6 \%$ of the seeds were fertilized by pollen from trees outside these stands. The average pollination distance within the forest fragment was $83 \mathrm{~m}$; when the tree group was
\end{abstract}

included the pollination distance was $2006 \mathrm{~m}$. The average number of effective pollen donors was estimated as 12.6. Mother-trees within the fragment could be assigned to all seedlings and juveniles, suggesting an absence of seed immigration. The distance of seedlings and juveniles from their assigned mother-trees ranged from 0.35 to $291 \mathrm{~m}$ (with an average of $83 \mathrm{~m}$ ). Significant spatial genetic structure among adult trees, seedlings, and juveniles was detected up to $50 \mathrm{~m}$, indicating seed dispersal over a short distance. The effective pollination neighborhood ranged from 0.4 to $3.3 \mathrm{ha}$. The results suggest that seed dispersal is restricted but that there is longdistance pollen dispersal between the forest fragment and the tree group; thus, the two stands of trees are not isolated.

Heredity (2007) 99, 580-591; doi:10.1038/sj.hdy.6801019; published online 10 October 2007

Keywords: Araucaria angustifolia; coniferous; microsatellite loci; spatial genetic structure; gene flow

\section{Introduction}

Genetic connectivity in populations of plants is determined by gene movements among them (Sork and Smouse, 2006). Gene flow in forest trees involves both pollen and seeds (Godoy and Jordano, 2001; Smouse and Sork, 2004). Male gametes are dispersed from the paternal to the maternal parent via pollen; in addition, embryos containing contributions from both parents are dispersed in the form of seeds (Hamrick et al., 1993). Patterns of pollen and seed dispersal greatly influence the genetic structure and effective size of plant populations (Adams, 1992; Dow and Ashley, 1998; Sousa and Hattemer, 2003). High levels of gene flow are expected to maintain genetic cohesion among populations, whereas low levels are thought to produce genetic differentiation through genetic drift and local selection.

Habitat fragmentation reduces areas of continuous forest to small, separate remnants and may decrease the effective size of tree populations (Cascante et al., 2002), disrupt the mating system and interrupt gene flow (Jump and Penuelas, 2006). When populations become geneti-

Correspondence: Dr AM Sebbenn, Seção de Genética Florestal, Instituto Florestal de São Paulo, CP 1322, Rua do Horto, São Paulo, São Paulo 01059-970, Brazil.

E-mail: alexandresebbenn@yahoo.com.br

Received 22 January 2007; revised 26 April 2007; accepted 23 May 2007; published online 10 October 2007 cally isolated, they are at risk of losing the genetic diversity that is critical to their long-term survival (Sork and Smouse, 2006). Forest fragmentation has been shown to produce an immediate loss of alleles that is associated with a reduction in population size (White et al., 1999; Jump and Penuelas, 2006). Additionally, mating systems and gene flow are disrupted, resulting in significantly elevated levels of inbreeding and population divergence and a reduction in genetic diversity within populations (Jump and Penuelas, 2006). However, the longevity of trees, combined with effective seed and pollen dispersal, can enhance their resistance to the negative effects of forest fragmentation (Hamrick, 2004; Jump and Penuelas, 2006). Thus, the key element for predicting the effects of fragmentation is the level of gene flow among populations (Hamrick, 2004).

Approaches based on microsatellite markers have been successfully used to estimate effective gene flow by comparing the segregation of genetic markers in parental and offspring cohorts (Lian et al., 2001; Burczyk et al., 2004a). Microsatellite markers provide a means of determining pollen donor patterns and level of gene flow through pollination and seed dispersal. The exclusion probability for paternity assignment is high owing to codominant inheritance and an elevated level of polymorphism (Dow and Ashley, 1998; Lian et al., 2001). The usual way to estimate pollen flow based on genetic markers is to use progeny arrays (seeds) sampled from individual seed-trees (Burczyk et al., 2004a). Movement 
of successful pollen can then be traced by examining the relative locations of identified maternal and paternal trees. External gene flow from pollen can be estimated from the proportion of pollinations in which all trees in a stand are excluded from paternity (Dow and Ashley, 1998; Streiff et al., 1999). This procedure provides estimates of effective pollen flow observed at the seed stage only (Burczyk et al., 2004a). Complementary, realized pollen flow can be observed in the regeneration and juvenile stages if the locations of these individuals and all potential male and female parents within the local population are known and analyzed by genetic markers (Burczyk et al., 2004a). Seed dispersal is more difficult to analyze this way since the use of exclusion methods is limited when both parents are unknown; moreover, it is not possible to distinguish father and mother-trees in hermaphroditic and monoecious species (Dow and Ashley, 1996; Godoy and Jordano, 2001; Hamrick, 2004; Burczyk et al., 2006). In dioecious species, likelihood methods for inferring maternity (maternity analysis) are particularly powerful when a pattern of mating can be assumed, as in, for example, a random mating model (Schnabel et al., 1998). These species are sexually distinct, with the reproductive parts of individual plants being solely male or solely female. Thus, male and female parents can be distinguished using maximum likelihood paternity assignment (Meagher and Thompson, 1986) if a sufficiently high number of polymorphic loci and all adult male and female reproductive individuals are sampled. When both male and female parents are identified, pollen and seed dispersal distance can be assessed (Meagher and Thompson, 1987). Meagher and Thompson (1987) successfully used this method to identify male and female parents and to quantify pollen and seed dispersal in a population of the dioecious long-lived perennial species Chamaelirium luteum in the United States.

Finally, within-population gene movements have been addressed by analyses of spatial genetic structure at a microgeographic level (Gonzalez-Martvnez et al., 2002; Hardy et al., 2004; Dutech et al., 2005; Jones and Hubbell, 2006)

We investigated patterns of pollen and seed dispersal in a small, isolated fragment of Araucaria angustifolia (Bert.) O. Ktze using eight nuclear microsatellite loci and applying a paternity likelihood approach. We also studied the effect of pollen immigration from a small, isolated group of $11 \mathrm{~A}$. angustifolia trees located at a distance of $1.7 \mathrm{~km}$ from the fragment. We tested two main hypotheses. First, in comparison with many other wind-pollinated coniferous species, A. angustifolia pollen is relatively large $(61.50 \mu \mathrm{m})$, non-saccate, has a reduced ability to float $(12.02-18.98 \mathrm{~cm} / \mathrm{s})$, and reaches the ground much more rapidly (Sousa and Hattemer, 2003). These factors, combined with the typically high population densities of Araucaria forests, can limit pollen movement between and within populations and reduce the number of pollen donors contributing to the next generation (Sousa and Hattemer, 2003; Sousa et al., 2005). In addition, the forest fragment we studied appeared to be physically isolated, resulting in the forest stand and the tree group being genetically separated from each other and from further stands. Therefore, we tested the hypothesis that pollen flow distance would be reduced. Second, the seeds of $A$. angustifolia are heavy, and are primarily dispersed by autochory under the canopy of the seed-trees, although they can be secondarily dispersed by birds, rodents and other mammals (Carvalho, 2003). Autochory can produce spatial genetic structure and mating among relatives if pollen flow occurs over short distances. Therefore, we tested the hypothesis that spatial genetic structure would be present in the forest fragment.

\section{Materials and methods}

\section{Studied species}

A. angustifolia (Paran $\alpha$ pine) is a subtropical, windpollinated, dioecious, coniferous tree species endemic to South America. It is an economically important tree in southern Brazil (Sousa et al., 2003), providing raw material for the pulp and paper industry and timber for construction. The natural distribution of the species in Brazil ranges from $19^{\circ} 15^{\prime} \mathrm{S}$ (Minas Gerais State) to $31^{\circ} 30^{\prime} \mathrm{S}$ (Rio Grande do Sul State). It can be also found in small patches in Argentina and Paraguay. The species grows exclusively in the tropical wet mixed forest (Araucaria forest) in the Alluvial (gallery), sub-Montana, Montana and high-Montana mountain formations, between altitudes of 500 and $2300 \mathrm{~m}$ (Carvalho, 2003). In the early 1900s, this species dominated the forests of southern Brazil in long, continuous, dense areas, but subsequent intensive exploitation and policies encouraging clear-cutting (Sousa et al., 2005) have resulted in less than $3 \%$ of the original Araucaria forest remaining (Carvalho, 2003).

\section{Study site}

The study was conducted in a 5.4 ha forest fragment localized on a farm and a small group of 11 isolated trees (group) about $1.7 \mathrm{~km}$ distant from the fragment (Figure 1). The study area is located on the plateau of Paran $\alpha$ State within the Iguanu catchments (latitude $25^{\circ} 57^{\prime} \mathrm{S}$ and longitude $\left.52^{\circ} 11^{\prime} \mathrm{W}\right)$. Geologically, the area is formed from Triassic/Cretaceous volcanic (Trapp) flows of the Serra Geral mountain formation. The climate is transitional between subtropical (Cfa) and temperate $(\mathrm{Cfb})$, according to the Koeppen classification. Average annual precipitation ranges from 1800 to $2100 \mathrm{~mm}$ and annual average temperature is $16-20^{\circ} \mathrm{C}$. The natural vegetation of the region is $A$. angustifolia forest associated with broad-leaved species. Fragmentation in this area dates from 1920 to 1980 and the current landscape is a mosaic of patches of agricultural land, pasture, remnant steppe, urban areas and forest. The study fragment is surrounded by intensive agricultural activity and pasture, and there is no other Araucaria forest nearby $(>4 \mathrm{~km})$. However, it is possible to observe isolated $A$. angustifolia trees or small groups of trees in the landscape. For these reasons, the selected fragment provided a good model for a study of the extent of potential isolation of a fragmented $A$. angustifolia population. In the forest fragment, regeneration can be found, adult trees are within different ages, and it is reasonable to assume that all seedlings and juvenile individuals were produced after the fragmentation. Before 1980, this fragment was also exploited by selective logging. In the site there are 124 male and 104 female $A$. angustifolia trees, with densities of 22.96 males, 19.26 females and 42.22 trees/ha. 


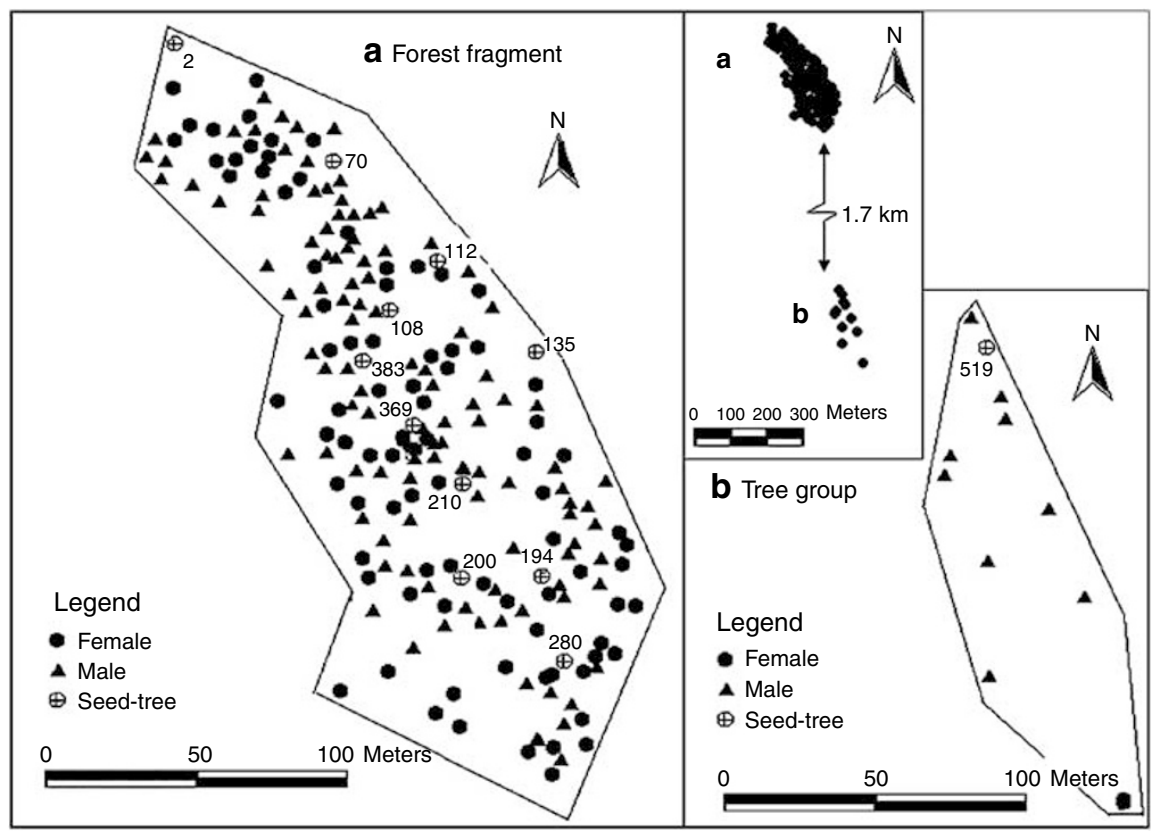

Figure 1 Map of A. angustifolia individuals in the analyzed forest fragment and the adjacent tree group.

Diameter at breast height (d.b.h.) ranges from 14.0 to $129.9 \mathrm{~cm}$, height varies from 7 to $27 \mathrm{~m}$ and age was estimated to range between 46 and 250 years. Minimum distances between two males, two females, and a male and female are 3, 3.2 and $4 \mathrm{~m}$, respectively. Maximum distances are 289.8, 334 and $331 \mathrm{~m}$, respectively, and average distances are 98.4, 108.1 and $104.3 \mathrm{~m}$, respectively. The nearest other $A$. angustifolia trees belong to a small group of 11 adults situated in a pasture. Nine of these trees are males and two are females. Their d.b.h. ranges from 40.7 to $82.8 \mathrm{~cm}$, their height ranges between 8.5 and $14.5 \mathrm{~m}$ and their age was estimated to range between 70 and 160 years.

\section{Sample collection}

In the forest fragment, cambium was sampled from all 228 adult trees (124 males and 104 females). For three males and five females it was not possible to obtain DNA extractions sufficient for microsatellite locus amplification. Thus, the genetic analysis was based on 121 males and 99 females. In the group, all 11 trees were sampled. The distinction into female and male in both stands were made by direct observation of male and female cones. Leaf samples were collected from all seedlings and juveniles. In total, samples were taken from 66 seedlings and 92 juveniles from regenerations within the fragment. We defined seedlings as individuals less than $3 \mathrm{~m}$ tall (0.35-3 m). Generally, under natural conditions, $A$. angustifolia trees start reproduction at about 20 years of age (d.b.h. $\geqslant 20 \mathrm{~cm}$, height $>10 \mathrm{~m}$ ), but early on the number of cones and male flowers is low. Thus, we defined trees without flowers, a d.b.h. $<25 \mathrm{~cm}$ and a height between 3 and $10 \mathrm{~m}$ as juveniles. The spatial positions of all sampled individuals (adult, seedlings and juveniles) in both forest fragment and tree group were recorded. Seeds were randomly collected from the canopy of 12 seed-trees: 11 in the fragment, and 1 female from the group. From each seed-tree about 20 seeds were randomly collected from one to three cones. In the fragment, the minimum distance between a sampled seed-tree and a male was $6 \mathrm{~m}$, the maximum was $331 \mathrm{~m}$, and the average was $99.4 \mathrm{~m}$. The minimum distance between seed-trees was $24.2 \mathrm{~m}$, the maximum was $298.6 \mathrm{~m}$ and the average was $106.5 \mathrm{~m}$. The cambium tissue was preserved in Eppendorf tubes with a solution of CTAB buffer (1/3) and ethanol (2/3) and stored at $-20^{\circ} \mathrm{C}$ before DNA extraction. Leaf samples from juveniles and seedlings were stored in silica gel at room temperature before DNA extraction. Sampled seeds were stored at a temperature of $-20^{\circ} \mathrm{C}$ before DNA extraction.

\section{DNA extraction and microsatellite analysis}

Total DNA was extracted from 220 adult trees, 66 seedlings, 92 juveniles and 230 seeds using the method of Mazza and Bittencourt (2000). DNA extraction from the seeds was adjusted slightly in that the megagametophyte (maternal origin) and embryo were extracted from 1 in every 20 open-pollinated seeds. The amplification and detection procedure for eight microsatellite loci are described in Salgueiro et al. (2005). The eight loci used were CRCAc2, Ag23, Ag62, Ag45, CRCAc1, Ag20, Ag56 and Ag94.

\section{Genetic diversity}

Genetic diversity for all sampled individuals from the forest fragment and from the group was characterized by the average number of alleles per locus $(A)$, observed heterozygosity $\left(H_{\mathrm{o}}\right)$ and expected heterozygosity in Hardy-Weinberg equilibrium $\left(H_{\mathrm{e}}\right)$. The total paternity probability of the first $\left(\operatorname{Pr}\left(E x_{1}\right)\right)$ and second parent $\left(\operatorname{Pr}\left(E x_{2}\right)\right)$ was also estimated. These analyses were conducted using the program CERVUS 2.0 (Marshall et al., 1998).

\section{Paternity analysis}

Paternity analysis of each seed, seedling and juvenile was carried out using maximum-likelihood paternity assignment. Paternity was assigned by comparing 
genotypes of adult males and seeds, females and males with seedlings and juveniles using the program CERVUS 2.0 (Marshall et al., 1998). To determine the putative pollen donor of the seeds, seedlings and juveniles, the analysis was performed using only male trees as parent candidates, since $A$. angustifolia is a dioecious species. To determine putative mother-trees, only reproductive female trees were used as parental candidates. Paternity or maternity was determined with base in $\Delta$ statistic (Marshall et al., 1998). To find the critical value of $\Delta$ for each confidence level in the paternity or maternity analyses, simulations were conducted using CERVUS 2.0. For these simulations we used 50000 repetitions, with 0.01 as the proportion of loci mistyped, $95 \%$ as strict and $80 \%$ as relaxed confidence level and 80 individuals as probable male candidate parents for each seed-tree. From the paternity analysis, pollen dispersal distance was calculated for seeds, seedlings and juveniles based on the position of the seed-tree or probable mother-tree (for seedlings and juveniles), and putative pollen parent within the forest fragment and the tree group. To determine whether male mating success is a function of distance between males and seed-trees, we also compared the frequency distribution of effective pollinating male parents with the frequency distribution of the distances among all males and the 11 seed-trees in the forest fragment. This process was carried out using the Kolmogorov-Smirnov test (Sokal and Rohlf, 1995). The effective seed dispersal distance was calculated based on the positions of the seedlings and juveniles relative to their putative maternal parents.

\section{Effective number of pollen donors, coancestry, inbreeding, variance effective size and effective neighborhood pollination area}

The effective number of pollen donors $\left(N_{\mathrm{ep}}\right)$ of each seedtree was estimated according to Burczyk et al. (1996) from the number of pollen donors $\left(n_{\mathrm{p}}\right)$ detected from paternity analysis results as $\hat{N}_{\mathrm{ep}}=1 / \sum_{i=1}^{n_{\mathrm{p}}} p_{i}^{2}$, where $n_{\mathrm{p}}$ is the number of embryos analyzed, $p_{\mathrm{i}}$ is the proportion of seeds sired by male $i$. From average over family effective number of pollen donors, we estimated the paternity correlation as $\hat{r}_{\mathrm{p}}=1 / \hat{N}_{\mathrm{ep}}$. On the basis of the paternity correlation, the average coancestry coefficient within families $\left(\Theta_{x y}\right)$ was estimated as $\hat{\Theta}_{x y}=$ $0.125\left(1+\hat{F}_{\mathrm{p}}\right)\left(1+\hat{r}_{\mathrm{p}}\right)$, where $F_{\mathrm{p}}$ is the inbreeding coefficient in the reproductive population (Sousa et al., 2005). The fixation index was estimated for adults $\left(F_{\mathrm{p}}\right)$, males $\left(F_{\mathrm{m}}\right)$, females $\left(F_{\mathrm{f}}\right)$, seeds $\left(F_{\mathrm{o}}\right)$, seedlings $\left(F_{\mathrm{s}}\right)$ and juveniles $\left(F_{\mathrm{j}}\right)$ as $\hat{F}=1-\left(\hat{H}_{\mathrm{o}} / \hat{H}_{\mathrm{e}}\right)$, where $H_{\mathrm{o}}$ is the observed heterozygosity, and $H_{\mathrm{e}}$ is the expected heterozygosity in Hardy-Weinberg equilibrium, using the GDA_NT program (Degen, 2006). The statistical significance of $F$ values was tested using Monte-Carlo permutation methods (Degen et al., 1999). The variance effective size $\left(N_{\mathrm{e}(\mathrm{v})}\right)$ for families was estimated as $\hat{N}_{\mathrm{e}(\mathrm{v})}=0.5 / \hat{\Theta}_{\mathrm{xy}}$ (Cockerham, 1969). S.e. was used to determine the $95 \%$ confidence interval for the parameters. The effective population size of the reproductive population of the forest fragment was calculated using the Cockerham (1969) estimator as

$$
\hat{N}_{\mathrm{e}}=\frac{0.5}{\hat{\Theta}_{\mathrm{xy}}((n-1) / n)+\left(\left(1+\hat{F}_{p}\right) / 2 n\right)},
$$

where $n$ is total number of individuals in the population, $F_{\mathrm{p}}$ is the inbreeding coefficient in the adult population, and $\Theta_{x y}$ is the group coancestry, calculated following the approach for dioecious species proposed by Lindgren and Mullin (1998):

$$
\hat{\Theta}_{\mathrm{xy}}=\frac{\sum_{x=1}^{n_{\mathrm{f}}} \sum_{y \neq 1}^{n_{\mathrm{f}}} \hat{\theta}_{\mathrm{f}}}{4 n_{\mathrm{f}}^{2}}+\frac{\sum_{x=1}^{n_{\mathrm{m}}} \sum_{y \neq 1}^{n_{\mathrm{m}}} \hat{\theta}_{\mathrm{m}}}{4 n_{\mathrm{m}}^{2}}+\frac{\sum_{x=1}^{n_{\mathrm{f}}} \sum_{y=1}^{n_{\mathrm{m}}} \hat{\theta}_{\mathrm{fm}}}{2 n_{\mathrm{f}} n_{\mathrm{m}}},
$$

where $\theta_{\mathrm{f}}, \theta_{\mathrm{m}}$ and $\theta_{\mathrm{fm}}$ are the coancestry coefficients between females, males and males and females together, respectively, and $n_{\mathrm{f}}$ and $n_{\mathrm{m}}$ are the number of female and male adult trees. The coancestry coefficients were calculated using Loiselle's estimator (described below) and the SPAGEDI program (Hardy and Vekemans, 2002). The effective neighborhood pollination area $\left(A_{\mathrm{ep}}\right)$ was calculated for each seed-tree from the pollen-dispersal variance $\left(\sigma^{2}\right)$, assuming a circular area around a central seed-tree, $\hat{A}_{\text {ep }}=2 \pi \hat{\sigma}^{2}$ (Levin, 1988).

\section{Spatial genetic structure}

Spatial genetic structure within the forest fragment was studied using the estimation of the average coancestry coefficient $\left(\theta_{x y}\right)$ between all pairs of adult trees, seedlings and juveniles. The $\theta_{x y}$ parameter measures the extent of relative similarity between individuals $x$ and $y$ relative to the mean genetic similarity between random individuals in the sample (Hardy and Vekemans, 2002). The coancestry coefficients were calculated using the estimator of Loiselle et al. (1995), which is defined for each $k$ th allele at the $l$ th locus in each pair of individuals, $x$ and $y$, as

$$
\hat{\theta}_{\mathrm{xy}}=\left[\frac{\sum_{l} \sum_{k}\left(p_{\mathrm{xlk}}-\bar{p}_{\mathrm{lk}}\right)\left(p_{\mathrm{ylk}}-\bar{p}_{\mathrm{lk}}\right)}{\sum_{l} \sum_{k} \bar{p}_{\mathrm{lk}}\left(1-\bar{p}_{\mathrm{lk}}\right)}\right]+\left[\sum_{l} \frac{1}{\left(2 n_{1}-1\right)}\right],
$$

where $p_{x l k}$ and $p_{y l k}$ are the frequencies of allele $k$ at the locus $l$ in the individuals $x$ and $y$, respectively (assuming values of $0,0.5$ and 1 in homozygote for alternative alleles, and heterozygote and homozygote individuals for the allele under consideration, respectively). $\bar{p}_{l k}$ is the average of the frequency of allele $k$ at locus $l$ in the sampled subpopulation, whereas $n_{1}$ is the number of genes defined in the sample at locus $l$ (number of individuals multiplied by the ploidy level minus the number of missing alleles). To visualize the spatial genetic structure, $\theta_{x y}$ values were averaged over a set of distance classes and plotted against the distances. We used $25 \mathrm{~m}$ distance intervals with a maximum distance of $250 \mathrm{~m}$ in each analysis. To test whether there was significant deviation from spatial genetic structure, the $95 \%$ confidence interval was calculated for each observed value and each distance class from 1000 permutations of individuals among locations. The confidence interval was used to construct the correlogram. These analyses were performed using the program SPAGEDI version 1.2 (Hardy and Vekemans, 2002). We also estimate the coancestry coefficients between seedlings and juveniles and their putative fathers and mothers assigned by paternity analysis. The expected coancestry coefficient for parent-sib relationships is 0.25 . 


\section{Results}

\section{Paternity assignment}

For the total sample, including all sampled individuals from the fragment (adults, juveniles, seedlings and seeds) and the group (adults and seeds), the number of alleles per locus ranged from 4 to 16 (average of 9.6 alleles), with a total of 77 alleles (Table 1). The observed heterozygosity ranged from 0.047 to 0.758 (average of 0.511 ), and the expected heterozygosity ranged from 0.062 to 0.863 (average of 0.596 ). The total paternity exclusion probabilities over eight loci of the first and second parent were 0.931 and 0.992 , respectively.

Of the 210 seeds sampled in the forest fragment, pollen donors could be assigned for 189 (90\%). Of the seeds sampled in the tree group, pollen donors were assigned for nine $(4 \%$, Table 2$)$. Of these 198 seeds $(189+9), 47$ were assigned based on a confidence level of $95 \%$ and 142 on a confidence level of $80 \%$. The other 12 seeds $(6 \%)$ are likely to represent pollen that originated from trees outside the study sites or from the three male trees in the forest fragment that were not genotyped. We determined

Table 1 Characteristics of eight microsatellite loci from Araucaria angustifolia in the analyzed forest fragment and tree group

\begin{tabular}{lcccccc}
\hline Locus & $\mathrm{n}$ & $\mathrm{k}$ & $\hat{\mathrm{H}}_{o}$ & $\hat{\mathrm{H}}_{e}$ & $\operatorname{Pr}\left(E x_{1}\right)$ & $\operatorname{Pr}\left(E x_{1}\right)$ \\
\hline CRCAc2 & 598 & 16 & 0.635 & 0.676 & 0.286 & 0.473 \\
Ag23 & 600 & 13 & 0.758 & 0.863 & 0.565 & 0.724 \\
Ag62 & 612 & 14 & 0.667 & 0.692 & 0.321 & 0.513 \\
Ag45 & 617 & 4 & 0.332 & 0.417 & 0.087 & 0.200 \\
CRCAc1 & 616 & 5 & 0.047 & 0.062 & 0.002 & 0.031 \\
Ag20 & 610 & 8 & 0.546 & 0.628 & 0.231 & 0.411 \\
Ag56 & 612 & 8 & 0.701 & 0.749 & 0.347 & 0.524 \\
As90 & 602 & 9 & 0.405 & 0.682 & 0.284 & 0.468 \\
Mean & & 9.6 & 0.511 & 0.596 & - & - \\
Total & & 77 & - & - & 0.931 & 0.992 \\
\hline
\end{tabular}

$H_{\mathrm{e}}$, expected heterozygosity; $H_{\mathrm{o}}$ observed heterozygosity; $k$ number of detected alleles per locus; $n$, sample size; $\left(\operatorname{Pr}\left(E x_{1}\right)\right)$, exclusion probability of the first; $\left(\operatorname{Pr}\left(E x_{2}\right)\right)$, exclusion probability of second parent. that, of the 121 potential pollen donors, 81 sired at least 1 seed. Of 20 seeds collected in the tree group from 1 female tree, pollen donors within the group could be assigned for 9 (45\%); 11 seeds (55\%) had pollen donors in the adjacent forest fragment. In the tree group, three males were assigned as fathers of the sample seeds and one of these males, located nearest $(11 \mathrm{~m})$ to the seed-tree, sired six of the nine seeds, according to the father assignment. Eleven different males from the forest fragment apparently sired the other seeds. Only one of these males is located in the northern part of the forest fragment. Seven males are located near the southern border of the fragment and three in the center (Figure 1a).

Mother-trees within the forest fragment were assigned to all 66 seedlings and 92 juveniles (Table 2). Of the 66 seedlings, nine were assigned based on a confidence level of $95 \%$ and 57 on a confidence level of $80 \%$. Of the 92 juveniles, 15 were assigned based on a confidence level of $95 \%$ and 77 on a confidence level of $80 \%$. Pollen donors within the forest fragment and group were assigned to 64 and 2 seedlings and 86 and 6 juveniles, respectively. Five of these seedling pollen donors were assigned based on a confidence level of $95 \%$ and 61 on a confidence level of $80 \%$; nine of the juvenile pollen donors were assigned based on a confidence level of $95 \%$ and 83 on a confidence level of $80 \%$. The average pair-wise coancestry coefficient and its standard error calculated among seedlings and putative mothertrees was $0.249 \pm 0.031$, and among seedlings and putative father trees it was $0.271 \pm 0.035$. For juveniles, these estimates were, respectively, $0.258 \pm 0.020$ and $0.254 \pm 0.025$. The $95 \%$ confidence standard error suggests that all these coancestry values are significantly different from zero.

\section{Distance of pollen movement}

Pollen was dispersed within the fragment over relatively short distances (Table 2; Figures 2a and b). The distances of pollen movement measured in the seed cohort ranged from 11 to $287 \mathrm{~m}$ (average of $83 \mathrm{~m}$; Table 2). The average

Table 2 Profiles of pollen flow for each seed-tree, seedlings and juveniles

\begin{tabular}{|c|c|c|c|c|c|c|c|c|}
\hline \multirow[t]{2}{*}{ Seed-tree } & \multirow[t]{2}{*}{$\mathrm{n}$} & \multicolumn{3}{|c|}{ Pollen flow (proportion) } & \multirow{2}{*}{$\hat{\mathrm{N}}_{e p}$} & \multicolumn{2}{|c|}{ Within fragment } & \multirow{2}{*}{$\frac{\text { Between fragment and group }}{\text { Distance }(m)}$} \\
\hline & & Fragment & Group & Outside & & Distance $(m)$ & $\hat{\mathrm{A}}_{e p}(h a)$ & \\
\hline Frag 2 & 18 & $17(0.94)$ & $0(0.00)$ & $1(0.06)$ & 14.7 & $133 \pm 64$ & 2.6 & $0 \pm 0$ \\
\hline Frag_70 & 18 & $12(0.67)$ & $3(0.17)$ & $3(0.17)$ & 16.2 & $90 \pm 64$ & 2.6 & $2069 \pm 60$ \\
\hline Frag 108 & 16 & $14(0.88)$ & $1(0.06)$ & $1(0.06)$ & 11.6 & $91 \pm 57$ & 2.0 & $1946 \pm 0$ \\
\hline Frag_112 & 20 & $17(0.85)$ & $3(0.15)$ & $0(0.00)$ & 12.5 & $100 \pm 46$ & 1.3 & $1927 \pm 0$ \\
\hline Frag_135 & 20 & $18(0.90)$ & $2(0.10)$ & $0(0.00)$ & 15.4 & $79 \pm 29$ & 0.5 & $1953 \pm 0$ \\
\hline Frag_194 & 18 & $16(0.89)$ & $0(0.00)$ & $2(0.11)$ & 11.6 & $85 \pm 71$ & 3.2 & $0.0 \pm 0$ \\
\hline Frag_200 & 20 & $18(0.90)$ & $0(0.00)$ & $2(0.10)$ & 14.3 & $91 \pm 34$ & 0.7 & $0.0 \pm 0$ \\
\hline Frag 210 & 20 & $19(0.95)$ & $0(0.00)$ & $1(0.05)$ & 9.1 & $53 \pm 26$ & 0.4 & $0.0 \pm 0$ \\
\hline Frag_280 & 20 & $19(0.95)$ & $0(0.00)$ & $1(0.05)$ & 9.5 & $80 \pm 44$ & 1.2 & $0.0 \pm 0$ \\
\hline Frag 369 & 20 & $19(0.95)$ & $0(0.00)$ & $1(0.05)$ & 12.4 & $76+50$ & 1.6 & $0.0 \pm 0$ \\
\hline Frag_383 & 20 & $20(1.00)$ & $0(0.00)$ & $0(0.00)$ & 11.8 & $78 \pm 36$ & 0.8 & $0.0 \pm 0$ \\
\hline Total & 210 & $189(0.90)$ & $9(0.04)$ & $12(0.06)$ & $12.6 \pm 2.3$ & $83 \pm 52$ & 1.7 & $2006 \pm 59$ \\
\hline Group_519 & 20 & $11(0.55)$ & $9(0.45)$ & $0(0.0)$ & 7.7 & $25 \pm 23$ & 0.3 & $1913 \pm 75$ \\
\hline Seedlings & 66 & $64(0.97)$ & $2(0.03)$ & $0(0.0)$ & - & $70 \pm 39$ & 1.0 & $1979 \pm 64$ \\
\hline Juveniles & 92 & $86(0.93)$ & $6(0.07)$ & $0(0.0)$ & - & $75 \pm 43$ & 1.2 & $1792 \pm 43$ \\
\hline
\end{tabular}

$n$, sample size; pollen flow from within fragment, tree group or outside of the fragment and tree group; effective number of pollen donors $\left(\hat{N}_{e p}\right)$; mean pollination distance within the fragment and between fragment and group (mean \pm s.d.); breeding neighborhood area $\left(\hat{A}_{e p}\right)$. 
a

Pollen dispersion
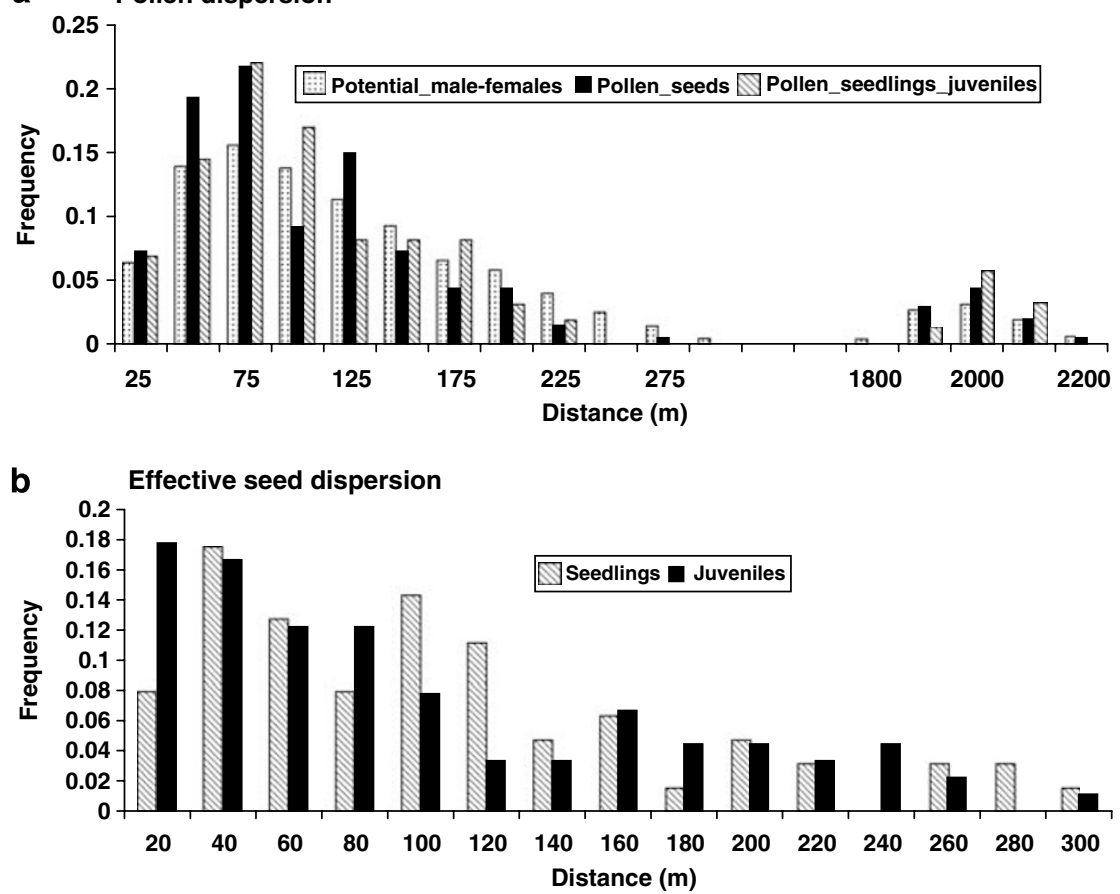

Figure 2 Frequency distribution of potential males and females, pollen-dispersal distances estimated from seeds, and from seedlings and juveniles (a), and seed-dispersal distances estimated from seedlings and juveniles (b) based on paternity analysis in a small forest fragment and tree group of $A$. angustifolia.

distances of pollen movement between mother and father assignments for the seedlings and juveniles were 70 and $75 \mathrm{~m}$, respectively. About $75 \%$ of the seed pollen and $80 \%$ of seedling and juvenile pollen traveled less than $150 \mathrm{~m}$ (Figure 2a). However, if the group was included in the analysis, comparatively high distances were detected. Mean pollen dispersal distances measured in seeds, seedlings and juveniles for pollen originating from the fragment were 2006, 1979 and $1792 \mathrm{~m}$, respectively, and for the seed cohort in the group the distance was $1913 \mathrm{~m}$ (Table 2).

There was a significant negative correlation between the number of seeds $\left(R^{2}=0.866, P<0.01\right)$, and seedlings and juveniles together $\left(R^{2}=0.687, P<0.01\right)$ fertilized by pollen donors and the distance between the paternal and maternal trees in the forest fragment. The comparison between the distribution of the potential and effective male parents as a function of the distance to the seedtrees depicts the departure from random mating (Figure 2a). The difference between the distance of pollen donors and all males in relation to the seed-trees (Figure 2a), as evaluated by the Kolmogorov-Smirnov test, was significant in seeds $(D=0.12, P<0.05)$ and in seedlings and juveniles together $(D=0.11, P<0.05)$, indicating that the distances between potential male parents and seed-trees cannot explain the observed mating patterns.

\section{Distance of realized gene flow}

The analysis of seedlings and juveniles showed short seed-dispersal distances (Figure 2b). The mothers of all analyzed seedlings and juveniles were found within the fragment, suggesting an absence of seed immigration. Seed dispersal distances for 66 seedlings and 92 juveniles in relation to their putative mothers ranged from 0.35 to $291 \mathrm{~m}$ (average of $92 \mathrm{~m}$ ). About $38 \%$ of the seedlings and $47 \%$ of the juveniles grew within a $60 \mathrm{~m}$ radius of the mother-tree and 60 and $67 \%$, respectively, grew within $100 \mathrm{~m} ; 83 \%$ of the seedlings and $80 \%$ of the juveniles grew within $160 \mathrm{~m}$ (Figure 2a). A significantly high negative correlation was observed between the number of seedlings $\left(R^{2}=0.5172, \quad P<0.01\right)$ and juveniles $\left(R^{2}=0.898, P<0.01\right)$ and the distances between mothertrees, seedlings and juveniles.

\section{Effective neighborhood pollination area}

On the basis of the seeds, the estimated effective neighborhood pollination area $\left(A_{\mathrm{ep}}\right)$ within the fragment ranged from 0.4 to 3.2 ha (average of 1.7 ha, Table 2 ). In the group, this area was 0.3 ha (Table 2). When $A_{\text {ep }}$ was estimated based on the seedlings and juveniles, it was quantified to be 1.0 and $1.2 \mathrm{ha}$, respectively. These areas correspond to a radius around the seed-trees ranging from 31 to $101 \mathrm{~m}$ (average of $74 \mathrm{~m}$ ).

\section{Fixation indices and effective population size in the reproductive population}

The fixation indices estimated for adults, male trees, female trees, seeds, seedlings and juveniles from the fragment (Table 3) were positive and significantly different from zero, suggesting deviations from HardyWeinberg equilibrium in the population. In the adult population (males and females) the fixation index was higher than in seeds. The highest fixation index was observed in seedlings $\left(\hat{F}_{\mathrm{s}}=0.197\right)$. Coancestry coefficients among females, males and males and females together were $0.00023,0.00103$ and 0.00034 , respectively (total $=0.00161)$. This indicates that, on random mating, 
Gene flow in Araucaria angustifolia JVM Bittencourt and AM Sebbenn

Table 3 Parameters estimated for inbreeding and mating systems in A. angustifolia

\begin{tabular}{lc}
\hline Parameter & Estimation \\
\hline Fixation index in adult generation: $F_{\mathrm{p}}$ & $0.150(0.064-0.278)^{*}$ \\
Fixation index in adult female trees: $F_{\mathrm{f}}$ & $0.115(0.007-0.244)^{*}$ \\
Fixation index in adult male trees: $F_{\mathrm{m}}$ & $0.176(0.085-0.310)^{*}$ \\
Fixation index in seeds: $F_{\mathrm{o}}$ & $0.082(0.023-0.164)^{*}$ \\
Fixation index in seedlings: $F_{\mathrm{s}}$ & $0.197(0.097-0.320)^{*}$ \\
Fixation index in juveniles: $F_{\mathrm{j}}$ & $0.124(0.015-0.294)^{*}$ \\
Paternity correlation: $\hat{r}_{p}=1 / \hat{N}_{e p}$ & $0.082(0.072-0.091)$ \\
Coancestry coefficient within families: & $0.155(0.145-0.171)$ \\
$\hat{\Theta}_{x y}=0.125\left(1+\hat{F}_{\mathrm{p}}\right)\left(1+\hat{r}_{\mathrm{p}}\right)$ & \\
Variance effective size: $\hat{N}_{\mathrm{e}(\mathrm{v})}=0.5 / \hat{\Theta}_{\mathrm{xy}}$ & $3.22(2.92-3.45)$ \\
\hline
\end{tabular}

( ) $95 \%$ confidence interval.

${ }^{*} P<0.05$.

expected biparental inbreeding is very low (0.00034). The estimated effective population size of the reproductive population indicated that 228 adult trees corresponded with 121 unrelated and inbreeding trees $\left(N_{\mathrm{e}} / N=0.53\right)$.

The number of pollen donors $\left(N_{\mathrm{ep}}\right)$ in the fragment ranged from 9.5 to 16.2, with an average of 12.6 per seedtree (Table 2). From $N_{\mathrm{ep}}$, the paternity correlation $\left(r_{\mathrm{p}}\right)$ was estimated to be 0.082 , indicating some correlated matings (Table 3$)$. The coancestry coefficient $\left(\Theta_{x y}\right)$ and variance effective size $\left(N_{\mathrm{e}(\mathrm{v})}\right)$ within progeny were higher than expected in half-sibs ( 0.125 and 4 , respectively).

Spatial genetic structure and estimation of gene dispersal We found a clear, fine-scale genetic structure within the fragment, indicated by significant positive coancestry coefficients between adult trees, seedlings and juveniles within the distance classes from 0 to $50 \mathrm{~m}$ (Figures $3 \mathrm{a}-\mathrm{c}$ ). The average coancestry coefficients for all pairwise adult trees, seedlings and juvenile comparisons, within the first distance class $(0-25 \mathrm{~m})$ were estimated to be 0.151 , 0.202 and 0.129 , respectively. These values are statistically different from zero, according to the $95 \%$ confidence interval (Figures $3 a-c)$. Coancestry coefficient values in the distance classes over $50 \mathrm{~m}$ decreased to near 0 .

\section{Discussion}

\section{Fragment isolation}

High levels of pollen flow were observed within the forest fragment, with low levels originating outside the fragment. Paternity analysis of the seeds indicated that $10 \%$ of the pollen came from male trees located outside the fragment, of which $4 \%$ originated from male trees located in a small tree group about $1.7 \mathrm{~km}$ away and $6 \%$ appeared to have been produced outside both stands and by trees over $1.7 \mathrm{~km}$ away. Similarly, paternity analysis indicated that only 3\% (seedlings) and 7\% (juveniles) of the realized pollen flow came from outside the fragment (male trees located in the tree group), and that all mothers were detected inside the fragment, indicating an absence of seed immigration. However, it is possible that our pollen immigration rate was underestimated since some foreign gametes may have multilocus genotypes that can also be generated by local males (cryptic gene flow). The probability of cryptic gene flow was high, at 0.478 (1-0.992; ${ }^{81}$ Dow and Ashley, 1996), and the number
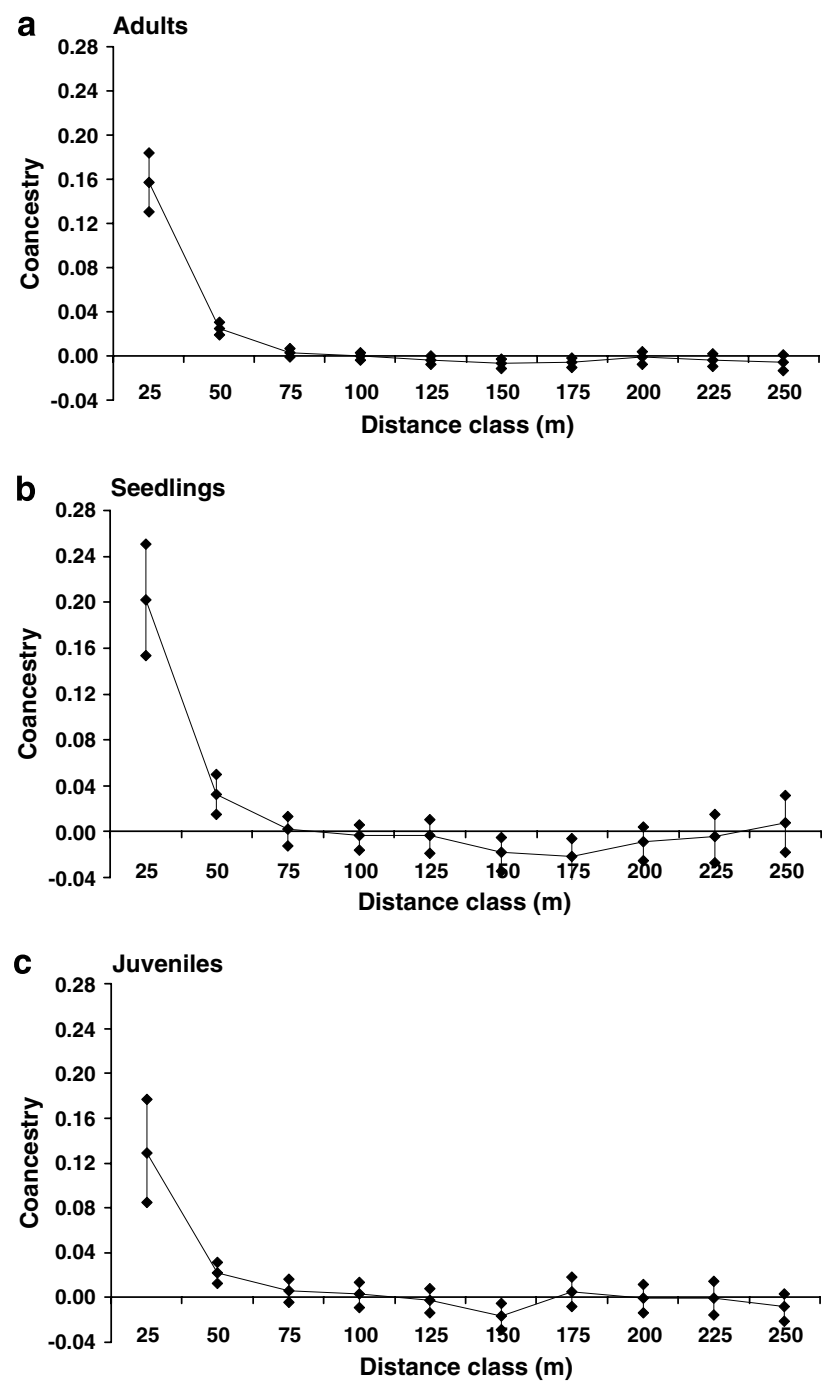

Figure 3 Graphs of coancestry coefficients $\left(\theta_{x y}\right)$ in 10 distance classes among adult trees (a), seedlings (b) and juveniles (c) within the $A$. angustifolia forest fragment (The vertical lines represent the 95\% confidence interval and the solid horizontal line represents the mean coancestry coefficient). ${ }^{*} P>0.05$.

of seeds that matched unrelated males by chance was estimated to be $90(189 \times 0.478)$. This represents $43 \%$ (90/ 210) of the total number of seeds sampled in the forest fragment. Thus, the levels of cryptic gene flow may have biased our pollen flow estimates and the actual pollen gene flow might be higher than $10 \%$ (between 10 and $47 \% \quad(189-90=99 / 210)$ of pollen immigration). The probability of cryptic gene flow in the tree group was low, at $0.07\left(1-0.992^{\circ}\right)$, and the number of seeds that matched unrelated males by chance was estimated to be $0.6(9 \times 0.07)$. This represents $3 \%(0.6 / 20)$ of the total number of seeds sampled in the forest fragment. Therefore, the levels of cryptic pollen flow would not have biased our results in the tree group.

Despite possible bias in the estimates, with a pollen flow $(m)$ ranging from 3 to $10 \%$, and an effective population size $\left(N_{\mathrm{e}}\right)$ in the reproductive population of about 121, we can expect a number of immigrants per generation $\left(N_{\mathrm{e}} m\right)$ ranging from 3.6 to 12.0 individuals. Consequently, genetic differentiation among the present population and other neighborhood populations can 
be expected to range between 0.020 and 0.217 $\left(\hat{F}_{\mathrm{ST}} \approx\left(4 N_{\mathrm{e}} m+1\right)^{-1}\right.$; Cockerham and Weir, 1993). These results agree with previous estimates of $F_{\mathrm{ST}}$ in $A$. angustifolia populations (ranging from 0.04 to 0.102 ) that showed low genetic differentiation and high historic gene flow among populations (Auler et al., 2002; Sousa et al., 2003).

The levels of long-distance pollen flow observed in the investigated $A$. angustifolia forest fragment are similar to those detected in other wind-pollinated tree species where the populations are isolated by more than $1 \mathrm{~km}$ (Table 4). For example, in a 15 ha Pinus flexilis stand isolated by $5 \mathrm{~km}$ from neighboring populations, pollen migration was calculated to be $6.5 \%$ (Schuster and Mitton, 2000), and in a 20 ha Pinus sylvestris stand isolated by $30 \mathrm{~km}$, pollen immigration was calculated to be $4.3 \%$ (Robledo-Arnuncio and Gil, 2005). However, these levels of pollen immigration are inferior to those detected in populations not isolated or located at lower distances from further stands (Table 4). For example, in a 5 ha Quercus macrocarpa stand isolated by more than $200 \mathrm{~m}$, the rate of pollen immigration was estimated to be 57\% (Dow and Ashley, 1998), and in a 9.12 ha stand of Pinus densiflora isolated by more than $100 \mathrm{~m}$ it was $31 \%$ (Lian et al., 2001). The present results suggest that the distance to the nearest stand is an important factor determining the rate of pollen immigration and the levels of isolation between the stands. The linear Spearman's correlation between the pollen immigration rate and isolation distance of the stands in Table 4 is negative and significantly different from zero $(\hat{r}=-0.606, P<0.05)$, supporting the intuitive hypothesis that more isolated stands receive less pollen immigration. It is likely that levels of pollen immigration decrease and isolation of stands increases with increasing distance between stands, following a typical isolation-by-distance model (Wright, 1943). Thus, high levels of genetic differentiation can be expected among distant remaining forest fragments of $A$. angustifolia.

\section{Tree group isolation}

The level of effective pollen flow into the analyzed tree group based on the study of seeds was high (55\%), indicating that these trees are not isolated. Pollen flow occurs in both directions, from forest fragment to group and vice versa. A large amount of successful pollen originated from a small number of adult male trees within the stand (three of the nine males). The male situated nearest $(11 \mathrm{~m})$ to the study mother-tree was responsible for $67 \%(6: 9)$ of the seeds assessed within the group. However, the results also suggest the possibility that there is a limitation to pollen flow, since the group is isolated from other $A$. angustifolia trees. All seeds produced by pollen from trees located outside the group have fathers in the adjacent forest fragment (11 trees), predominantly at the southern border of the fragment. The tree group is located in an intensively used agricultural landscape and the probability of its seeds growing into new trees is practically null. However, the pollen contribution of the group to the fragment is important in increasing the effective size.

\section{Distance of pollen flow}

The present population of $A$. angustifolia presents two levels of pollen dispersal, a short-distance component within the fragment and a long-distance component between the fragment and the group (Figures $2 a$ and $b$ ). Both short and long pollen dispersal distances have been observed in other wind-pollinated species (see Dow and

Table 4 Estimates of pollen flow into populations of wind-pollinated tree species based on paternity analysis

\begin{tabular}{|c|c|c|c|c|}
\hline Species & Stand size (ha) & Isolation $(m)$ & Immigration rate (\%) & Reference \\
\hline \multicolumn{5}{|c|}{ Relative high levels of geographic isolation } \\
\hline Araucaria angustifolia & $5.4^{\mathrm{a}}$ & $>1700$ & 10 & This study \\
\hline Picea abies & $1.0^{\mathrm{b}}$ & $>4000$ & 16 & Xie and Knowles (1994) \\
\hline Picea glauca & - & $>1000$ & 1.0 & Adams and Burczyk (2000) \\
\hline Pinus flexilis & $15^{\mathrm{a}}$ & $>5000$ & 6.5 & Schuster and Mitton (2000) \\
\hline Pinus sylvestris & $20^{\mathrm{a}}$ & $>5000$ & 4.3 & Robledo-Arnuncio and Gil (2005) \\
\hline Pinus sylvestris & $22.9^{c}$ & $>2000$ & 48 & Harju and Nikkanen (1996) \\
\hline Mean & & & 14.3 & \\
\hline \multicolumn{5}{|c|}{ Relative low levels of geographic isolation } \\
\hline Cercidiphyllum japonica & $20^{\mathrm{a}}$ & $>500$ & 28 & Sato et al. (2006) \\
\hline Fraxinus excelsior & - & $>600$ & $46-95$ & Bacles et al. (2005) \\
\hline Picea abies & $13.2^{\mathrm{c}}$ & 0 & 70 & Pakkanen et al. (2000) \\
\hline Picea abies & $0.89^{c}$ & $>100$ & 83 & Burczyk et al. (2004b) \\
\hline Pinus attenuata & $0.04^{\mathrm{a}}$ & $>11$ & 56 & Burczyk et al. (1996) \\
\hline Pinus densiflora & $9.12^{\mathrm{a}}$ & $>100$ & 31 & Lian et al. (2001) \\
\hline Pinus taeda & $2.0^{\mathrm{C}}$ & $>200$ & 36 & Friedman and Adams (1985) \\
\hline Pseudotsuga menziesii & $2.4^{\mathrm{a}}$ & 0 & 27 & Adams (1992) \\
\hline Pseudotsuga menziesii & $2^{c}$ & 0 & 49 & Adams et al. (1997) \\
\hline Pseudotsuga menziesii & - & $>100$ & 70 & Smith and Adams (1983) \\
\hline Quercus macrocarpa & $5.0^{\mathrm{a}}$ & $>200$ & 60 & Dow and Ashley (1998) \\
\hline Quercus petrae & $5.8^{\mathrm{a}}$ & 0 & 69 & Streiff et al. (1999) \\
\hline Quercus robur & $5.8^{\mathrm{a}}$ & 0 & 65 & Streiff et al. (1999) \\
\hline Quercus robur & $4.5^{\mathrm{c}}$ & $>400$ & 70 & Buiteveld et al. (2001) \\
\hline Mean & & & 54.3 & \\
\hline
\end{tabular}

${ }^{\mathrm{a}}$ Natural population.

blantation.

'Seed orchard. 
Ashley, 1998; Streiff et al., 1999; Schuster and Mitton, 2000; Lian et al., 2001; Bacles et al., 2005; RobledoArnuncio and Gil, 2005; Valbuena-Carabana et al., 2005; Goto et al., 2006). Within the fragment, the average pollen dispersal distance was less than $100 \mathrm{~m}$ and at least $75 \%$ of the pollen was dispersed within a distance of $150 \mathrm{~m}$ (Figures $3 a-c)$. This average is higher than the average detected for the wind-pollinated trees Pinus attenuata (5.43 m, Burczyk et al., 1996), Quercus robur (22.1-58.41 m; Streiff et al., 1999), Quercus petraea (18.41-64.56 m; Streiff et al., 1999), Fagus silvatica (50 m; Wang and Hattemer, 2001) and Pinus densiflora (68 m; Lian et al., 2001), and similar to the distance observed in Pinus sylvestris $(83 \mathrm{~m}$; Robledo-Arnuncio and Gil, 2005), but shorter than that calculated for Pinus flexilis (140 m; Schuster and Mitton, 2000) and Fraxinus excelsior ( $328 \mathrm{~m}$; Bacles et al., 2005). Thus, compared with other wind-pollinated species, $A$. angustifolia can disperse pollen over relatively long distances within the study stand, despite the fact that it has non-saccate and large pollen grains. However, the study stand is small, favoring pollen movement. Further studies of pollen dispersal within large, continuous fragments are needed to confirm the pollen dispersal distances observed here.

The characteristics of $A$. angustifolia pollen and typical high densities of Araucaria forests may cause the high proportion of matings within a distance of $150 \mathrm{~m}$ and some of the correlated mating $\left(\hat{r}_{\mathrm{p}}=0.082\right)$. A. angustifolia pollen has a reduced ability to float in the air, and the typically high densities of Araucaria forests can create barriers to pollen movement, limiting the distance of pollen dispersal within the forests (Sousa and Hattemer, 2003). El-Kassaby and Jaquish (1996) noted this trend when comparing populations with different densities in Larix occidentalis, observing low and nonsignificant levels of correlated matings (0.001 and 0.024) in low-density populations, and higher and significant levels of correlated matings (0.062 and 0.104) in high-density populations. They suggested that a high tree density limits pollen movement within populations. Sousa et al. (2005) detected paternity correlations in $13 \mathrm{~A}$. angustifolia populations ranging from 0.110 to 0.602 . The highest paternity correlation was observed in a 37-year-old $A$. angustifolia plantation with a high density (294 trees/ha), indicating that population density may affect the rate of correlated mating in the species. Dyer and Sork (2001) also observed restricted pollen movement within a Pinus echinata continuous forest and reported a negative association between the distance of pollen dispersal and total tree density. A similar situation is likely to exist with A. angustifolia.

Another factor that can produce correlated mating in A. angustifolia is the variation in individual fertility. Mantovani et al. (2006a) studied the reproductive phenology in a population in Campos do Jord $\gamma_{0}, \mathrm{~S} \gamma \mathrm{O}$ Paulo State during two consecutive years and observed that pollen dispersal and female fertility extend from August to September. Male and female flowering seem to be synchronous, but male flowering phenology showed individual variations in timing and intensity, and some trees tended to produce more strobilos than others, indicating that some males yield more pollen than others (Mantovani et al., 2006a). A high proportion of pollen from a small number of individuals could produce correlated matings.
Limitations to pollen dispersal within Araucaria forests can produce genetic heterogeneities in pollen gene frequencies among female reproductive trees by correlated matings within small neighborhood pollination areas, increasing the coancestry coefficients within progenies and reducing the variance effective population size. We observed a small average effective pollination neighborhood (1.7 ha) with a coancestry coefficient within families that was higher than expected in halfsib families $\left(\Theta_{x y}=0.155\right)$ and a low variance in effective size within families $\left(\hat{N}_{\mathrm{e}(\mathrm{v})}=3.22\right)$. The calculated $A_{\mathrm{ep}}$ is 3.2 times smaller than the area of forest fragment and represents the area where we can expect to find $63 \%$ of the pollen parents of a central seed-tree.

The second level of pollen dispersal occurs between the fragment and the tree group, indicating a long pollen-dispersal distance. This result contradicts the hypothesis that pollen flow distance in A. angustifolia is low. The long distance of effective pollen dispersal can be explained by high wind intensities and the absence of physical barriers between the fragment and the tree group. Considering these results, we can expect similar levels of pollen flow among populations less than $2 \mathrm{~km}$ apart.

\section{Number of pollen donors}

Our paternity analysis revealed a large number of pollen donors mating with each seed-tree $\left(\hat{N}_{\mathrm{ep}}=12.6\right.$; Table 2$)$, indicating that wind is an efficient pollen dispersal vector. However, considering that each $A$. angustifolia cone contains about 200 seeds (Carvalho, 2003) and that there are only 124 reproductive males in the study population, all of the cones will represent a mixture of half-sibs and full-sibs, and the variance in effective population size will be less than the maximum expected in a panmictic population $\left(\hat{N}_{\mathrm{e}(\mathrm{v})}<0.5 / \Theta_{\text {half-sibs }}=0.5 /\right.$ $0.125=4)$, even with random mating. In addition, the detected spatial genetic structure in the fragment will probably lead to some matings between relatives and to biparental inbreeding. The estimated difference between multilocus and single-locus outcrossing rates in the present data suggests the occurrence of an expressive rate of matings among relatives $\left(\hat{t}_{\mathrm{m}}-\hat{t}_{\mathrm{s}}=0.172 \pm 0.018\right.$, $P<0.01$, analysis not shown), explaining the observed positive and significant fixation indices in the seeds, seedlings and juveniles (Table 3).

\section{Realized gene flow}

Our results confirm the hypothesis that seeds in $A$. angustifolia are generally dispersed near the seed-trees. The analysis of fine-scale genetic structure within the fragment detected spatial genetic structure for adult trees, seedlings and juveniles in the distance classes up to $50 \mathrm{~m}$ (Figures $3 \mathrm{a}-\mathrm{c}$ ). The average coancestry coefficients were between those expected for half-sibs (0.125) and full-sibs or parent-sibs (0.25). Accordingly, the paternity analysis detected mother-trees of all seedlings and juveniles within the forest fragment. The average distance between seedlings, juveniles and putative mother-trees is approximately $92 \mathrm{~m}$ and about $60 \%$ of the seedlings and $67 \%$ of the juveniles grow within a radius of $100 \mathrm{~m}$ of the mother-trees (Figure 2b). In addition, the estimated average value of pair-wise coancestry coefficients among seedlings, juveniles and 
mother-trees was near that expected for parent-seed relationships (0.25), confirming the results obtained in the paternity analysis. Spatial genetic structure has also been detected in other stands of A. angustifolia (Mantovani et al., 2006b). Spatial genetic structure in current $A$. angustifolia forests was expected, considering the high population density (42.2 adult trees/ha), the largeness of the seeds and the fact that seed dispersal in this species occurs primarily by autochory, although the higher density of female trees in the population (19.26 female trees/ha) could have reduced the amount of spatial structure within the stand, owing to the overlap of seed shadows. However, not all females produce seeds every year (Mantovani et al., 2006a), and the overlap of seed shadows may not be great enough to reduce the levels of spatial genetic structure. This, combined with the high rate of short-distance pollen dispersal, explains the observed biparental inbreeding in the population, as discussed in a previous section.

\section{Fixation indices}

The results showed that there was significant biparental inbreeding in all ontogenic study stages and that the population was not in Hardy-Weinberg equilibrium. However, the fixation index detected in sampled seeds was lower than that detected in adults, suggesting selection against heterozygote individuals. This contradicts the pattern observed in many other tree species, where higher fixation indices have been detected in progenies than in adult trees, suggesting selection against inbred individuals between the seed and adult phases. The high fixation index in adult trees might be attributable to the Wahlund effect rather than biparental inbreeding per se, considering the fact that the population is genetically structured. Thus, we used the classical relation among $F$-statistics, $\left(1-F_{\mathrm{IT}}\right)=\left(1-F_{\mathrm{IS}}\right)\left(1-F_{\mathrm{ST}}\right)$ (Wright, 1965) to derive the part of the fixation index in adult trees that originates exclusively in the mating system (biparental inbreeding). In Wright's expression, $F_{\text {IT }}$ represents the fixation index of an individual relative to the total population, and can be attributed to a combination of mating system (biparental inbreeding in dioecious species) and Wahlund effect. In this sense, $F_{\mathrm{IT}}=F_{\mathrm{p}}$ since $F_{\mathrm{p}}$ was calculated using all individuals in the population (same and different subpopulations), $F_{\text {IS }}$ is the fixation index of an individual relative to the subpopulation and this statistic is affected only by the mating system. The $F_{\mathrm{ST}}$ statistic corresponds to the coancestry coefficient among individuals within subpopulations (attributed to genetic drift-the Wahlund effect). In this way, we can assume that $F_{\mathrm{ST}}=\theta_{x y}$ and that the present adult population is subdivided into many circular subpopulations within a radius of $25 \mathrm{~m}$, where the higher values of coancestry coefficients from spatial genetic analyses were observed. The fixation index originating in the mating system was estimated as $\hat{F}_{\text {IS }}=1-\left(\left(1-\hat{F}_{\mathrm{p}}\right) /\left(1-\hat{\theta}_{x y}\right)\right)$. The use of the last expression gave another picture of the genetic structure of the population. We conclude that in the adult population there is no biparental inbreeding $\left(F_{\mathrm{IS}}=-0.008\right)$, and that the previous positive $F_{\mathrm{p}}$ value probably reflects the spatial genetic structure of the population. A comparison of this value with the fixation index estimated in the seeds suggests that, in the study population, the strongest selection against inbreeding occurs between the seed and adult phases (inbreeding depression), in agreement with what has been observed in many other tree species.

\section{Implications for conservation, tree breeding and seed harvesting}

These results have important implications for seed collection strategies for ex situ conservation of $A$. angustifolia, tree breeding and reforestation. The presence of spatial genetic structure in the fragment indicates that seeds for ex situ conservation or tree breeding should be collected from trees at least $100 \mathrm{~m}$ apart to reduce relatedness among harvested seed-trees. The inclusion of related families in $e x$ situ germplasm and progeny tests reduces the effective population size and results in genetic parameters, such as heritability and genetic gains, being overestimated. However, considering the finite number of males within the fragment, the detected spatial genetic structure within $50 \mathrm{~m}$, and the fact that $75-80 \%$ of the effective pollen originates from within a radius of $150 \mathrm{~m}$ around the seed-tree, we can expect that seeds will be composed of a mixture of half-sibs and fullsibs and, furthermore, represent some level of biparental inbreeding. Thus, estimates of genetic parameters in progeny tests using seeds from small forest fragments ( $<10$ ha) need to be corrected to accommodate correlated matings and biparental inbreeding. The comparably high detected pollen flow distance suggests that seed orchards need to be geographically isolated by more than $1.7 \mathrm{~km}$, preferentially more than $3 \mathrm{~km}$, from the nearest Araucaria stand to avoid pollen contamination. The relatively high number of pollen donors across seed-trees in the fragment indicates that female trees in the isolated groups throughout the landscape are suitable for seed collection. Finally, pollen immigration into the fragment from isolated groups of trees highlights the importance of such groups of trees in the promotion of genetic variation, reduction of coancestry and inbreeding, and increase in effective population size in the fragments.

\section{Acknowledgements}

JVB would like to thank the Conselho National of Desenvolvimento Cientvfico e Tecnologico (CNPq) for granting her a PhD scholarship at the University of Reading (UK). AMS is supported by a CNPq postdoctoral scholarship at the Institute for Forest Genetics and Forest Plant Breeding, Federal Research Center for Forestry and Forest Products, Germany. The authors thank Jutta Buschbom and Carlos Eduardo Svcole Seoane for discussion and important suggestions for an earlier version of the manuscript. We also thank to Associated Editor Thomas R Meagher and two anonymous referees for important suggestions and constructive criticism of the previous article, and Judy McBride for final corrections to the English.

\section{References}

Adams WT (1992). Gene dispersal within forest tree populations. Forest Sci 6: 217-240.

Adams WT, Burczyk J (2000). Magnitude and implications of gene flow in gene conservation reserves. In: Young $\mathrm{A}$, Boshier D, Boyle T (eds). Forest Conservation Genetics: 
Principles and Practice. CSIRO Publishing: Collingwood, Australia. pp 215-224.

Adams WT, Hipkins VD, Burczyk J, Randall WK (1997). Pollen contamination trends in a maturing Douglas-fir seed orchard. Can J For Res 27: 131-134.

Auler NMF, Reis MS, Guerra MP, Nodari RO (2002). The genetics and conservation of Araucaria angustifolia: I. Genetic structure and diversity of natural populations by of means of non-adaptive variation in the state of Santa Catarina. Genet Mol Biol 25: 329-338.

Bacles CFE, Burczyk J, Lowe AJ, Ennos RA (2005). Historical and contemporary mating patterns in remnant populations of the forest tree Fraxinus excelsior L. Evolution 59: 979-990.

Buiteveld J, Bakker EG, Bovenshen J, Vries SMG (2001) Paternity analysis in a seed orchard of Quercus robur L. and estimation of the amount of background pollination using microsatellite markers. Forest Genet 8: 331-337.

Burczyk J, Adams WT, Birkes DS, Chalupka W (2006). Using genetic markers to direct estimate gene flow and reproductive success parameters in plants on the basis of naturally regenerated seedlings. Genetics 173: 363-372.

Burczyk J, Adams WT, Shimizu JY (1996). Mating patterns and pollen dispersal in a natural knobcone pine (Pinus attenuata Lemmon) stand. Heredity 77: 251-260.

Burczyk J, DiFazio SP, Adams WT (2004a). Gene flow in forest trees: how far do genes really travel? Forest Genet 11: 1-14.

Burczyk J, Lewandowski A, Chalupka W (2004b). Local pollen dispersal and distance gene flow in Norway spruce (Picea abies [L.] Karst.). Forest Ecol Manage 197: 39-48.

Carvalho PER (2003). Espıcies Arboreas Brasileiras. Embrapa

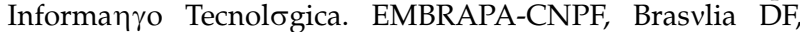
Cockerham CC (1969). Variance of gene frequencies. Evolution 23: 72-84.

Cascante A, Quesada M, Lobo JJ, Fuchs EA (2002). Effects of dry tropical forest fragmentation on the reproductive success and genetic structure of the tree Samanea saman. Cons Biol 16: 137-147.

Cockerham CC (1969). Variance of gene frequencies. Evolution 23: $72-84$.

Cockerham CC, Weir BS (1993). Estimation of gene flow from F-statistic. Evolution 47: 855-863.

Degen B (2006). Genetic data analysis and numerical test. GDA-NT. Beta version 1.0. Available from b.degen@holz. uni-hamburg.de.

Degen B, Streiff R, Ziegenhagen B (1999). Comparative study of genetic variation and differentiation of two pedunculate oak (Quercus robur) stands using microsatellite and allozyme loci. Heredity 83: 597-603.

Dow BD, Ashley MV (1996). Microsatellite analysis of seed dispersal and parentage of sampling in bur oak, Quercus macrocarpa. Mol Ecol 5: 615-627.

Dow BD, Ashley MV (1998). High levels of gene flow in bur oak revealed by paternity analysis using microsatellites. $J$ Hered 89: 62-70.

Dutech C, Sork VL, Irwin A, Smouse PE, Davis FW (2005). Gene flow and fine-scale genetic structure in a windpollinated tree species, Quercus lobata (Fagaceae). Am J Bot 92: 252-261.

Dyer RJ, Sork LJ (2001). Pollen pool heterogeneity in shortleaf pine, Pinus echinata Mill. Mol Ecol 10: 859-866.

El-Kassaby YA, Jaquish B (1996). Population density and mating pattern in western larch. J Hered 87: 438-443.

Friedman ST, Adams WT (1985). Estimation of gene flow into two seed orchards of loblolly pine (Pinus taeda L.). Theor Appl Genet 69: 609-615.

Godoy JA, Jordano P (2001). Seed dispersal by animal: exact identification of source trees with endocarp DNA microsatellites. Mol Ecol 10: 2275-2283.

Gonzalez-Martvnez SC, Gerber S, Cervera MT, MartvnezZapater JM, Gil L, Alva R (2002). Seed gene flow and finescale structure in a Mediterranean pine (Pinus pinastes Ait.) using nuclear microsatellite markers. Theor Appl Genet 104: 1290-1297.

Goto S, Shimatani K, Yoshimaru H, Takahashi Y (2006). Fattailed gene flow in the dioecious canopy tree species Fraxinus mandshurica var. japonica revealed by microsatellites. Mol Ecol 15: $2985-2996$.

Hamrick JL (2004). Response of forest trees to global environmental changes. Forest Ecol Manage 197: 323-335.

Hamrick JL, Murawski DA, Nason JD (1993). The influence of seed dispersal mechanisms on the genetic structure of tropical tree populations. Vegetation 107/108: 281-297.

Hardy O, Vekemans X (2002). SPAGeDI: a versatile computer program to analyze spatial genetic structure at the individual or population levels. Mol Ecol Notes 2: 618-620.

Hardy OJ, Gonzalez-Martvnez S, Colas B, Frıville H, Mignot A, Olivieri I (2004). Fine-scale genetic structure and gene dispersal in Centaurea corymbosa (Asteraceae). II. Correlated paternity within and among sibships. Genetics 168: 16011614.

Harju AM, Nikkanen T (1996). Reproductive success of orchard and non-orchard pollen during different stages of pollen shedding in a Scots pine seed orchard. Can J For Res 26: 10961102.

Jones FA, Hubbell SP (2006). Demographic spatial genetic structure of the Neotropical tree, Jacaranda copaia. Mol Ecol 15: 3205-3217.

Jump AS, Penuelas J (2006). Genetic effects of chronic habitat fragmentation in a wind-pollinated tree. Proc Natl Acad Sci USA 103: 8096-8100.

Levin DA (1988). The paternity pool plants. Am Nat 132: 309317.

Lian C, Miwa M, Hogetsu T (2001). Outcrossing and paternity analysis of Pinus densiflora (Japanese red pine) by microsatellite polymorphism. Heredity 87: 88-98.

Lindgren D, Mullin TJ (1998). Relatedness and status number in seed orchard crops. Can J For Res 28: 276-283.

Loiselle BA, Sork VL, Nason J, Graham C (1995). Spatial genetic structure of a tropical understory shrub, Psychotria officinalis (Rubiaceae). Am J Bot 82: 1420-1425.

Mantovani A, Morellato LPC, Reis MS (2006a). Fenologia reprodutiva e produๆ $\gamma$ o de sementes em Araucaria angustifolia (Bert.) O. Kuntze. Rev Bras Bot 27: 787-796.

Mantovani A, Morellato LPC, Reis MS (2006b). Internal genetic structure and outcrossing rate in a natural population of Araucaria angustifolia (Bert.) O. Kuntze. J Hered 97: 466-472.

Marshall TC, Slate J, Kruuk LEB, Pemberton JM (1998). Statistical confidence for likelihood-based paternity inference in natural populations. Mol Ecol 7: 639-655.

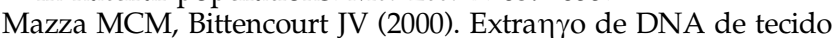
de Araucaria angustifolia (Araucariacea). Bol Pesq Flor 41: 12-17.

Meagher TR, Thompson E (1986). The relationship between single parents and parent pair genetic likelihoods in genealogy reconstruction. Theor Pop Biol 29: 87-106.

Meagher TR, Thompson E (1987). Analysis of parentage for naturally established seedlings of Chamaelirim luteum (Liliaceae). Ecology 68: 803-812.

Pakkanen A, Nikkanen T, Pulkkinen P (2000). Annual variation in pollen contamination and outcrossing in a Picea abies seed orchard. Scand J For Res 15: 399-404.

Robledo-Arnuncio JJ, Gil L (2005). Patterns of pollen dispersal in a small population of Pinus sylvestris L. revealed by totalexclusion paternity analysis. Heredity 94: 13-22.

Salgueiro F, Caron H, De Sousa MIF, Kremer A, Margis R (2005). Characterization of nuclear microsatellite loci in South American Araucariaceae species. Mol Ecol Notes 5: 256-258.

Sato T, Isakio Y, Osumi K, Goto S (2006). Effect of gene flow on spatial genetic structure in the riparian canopy tree Cercidiphyllun japonicum revealed by microsatellite analysis. Heredity 96: 79-84.

Schnabel A, Nason JD, Hamrick JL (1998). Understanding the population genetic structure of Gleditsia triacanthos L: seed 
dispersal and variation in female reproductive success. Mol Ecol 7: 819-832.

Schuster WSF, Mitton JB (2000). Paternity and gene dispersal in limber pine (Pinus flexilis James). Heredity 84: 348-361.

Smith DB, Adams WT (1983). Measuring pollen contamination in clonal seed orchards with the aid of genetic markers. In: Bongarten BC, Yates HO (eds). Proceedings of the 17th Southern Forest Tree Improvement Conference; 6-9 June 1983; pp, 69-77. Athens: Georgia, USA. The National Technical Information Service: Springfield, 1983, pp, 69-77.

Smouse PE, Sork VL (2004). Measuring pollen flow in forest trees: an exposition of alternative approaches. Forest Ecol Manage 197: 21-38.

Sokal RR, Rohlf FJ (1995). Biometry: Principles and Practices of Statistics in Biological Research, 3rd edn. W.H. Freeman and Company: New York.

Sork VL, Smouse PE (2006). Genetic analysis of landscape connectivity in tree populations. Landscape Ecol 21: 821-836.

Sousa VA, Hattemer HH (2003). Pollen dispersal and gene flow by pollen in Araucaria angustifolia. Austr J Bot 51: 309-317.

Sousa VA, Robinson IP, Hattemer HH (2003). Variation and population structure at enzyme gene loci in Araucaria angustifolia (Bert.) O. Ktze. Silvae Genet 53: 12-19.

Sousa VA, Sebbenn AM, Hattemer H, Ziehe M (2005). Correlated mating in populations of a dioecious Brazilian conifer, Araucaria angustifolia (Bert.) O. Ktze. Forest Genet 12: 107-119.

Streiff R, Ducousso A, Lexer C, Steinkellner H, Gloessl J, Kremer A (1999). Pollen dispersal inferred from paternity analysis in a mixed oak stand of Quercus robur $\mathrm{L}$. and $Q$. petraea (Matt.) Liebl. Mol Ecol 8: 831-841.

Valbuena-Carabana M, Gonzalez-Martvnez SC, Sork VL, Collada C, Soto A, Goicoechea PG et al. (2005). Gene flow and hybridization in a mixed oak forest (Quercus pyrenaica Willd. and Quercus petraea (Matts.) Liebl.) in central Spain. Heredity 95: 457-465.

Wang K, Hattemer HH (2001). Dispersal of seed and effective pollen in small stands of European beach (Fagus sylvatica). In Müller-Starck G, Schubert R (eds). Genetic Response of Forest Systems to Changing Environmental Conditions, vol. 70. Kluwer Academic Publishers: London. pp 259-269.

White GM, Boshier DH, Powell W (1999). Genetic variation within a fragmented population of Swietenia humilis Zucc. Mol Ecol 8: 1899-1909.

Wright S (1943). Isolation by distance. Genetics 28: 114-138.

Wright $S$ (1965). The interpretation of population structure by $F$ statistics with special regard to systems of mating. Evolution 19: 395-420.

Xie CY, Knowles P (1994). Mating system and effective pollen immigration in a Norway spruce (Picea abies (L.) plantation. Silvae Genet 43: 48-52. 